\title{
ENFORCING JURISDICTION AGAINST VESSELS SUSPECTED OF MIGRANT SMUGGLING AND HUMAN TRAFFICKING
}

\section{EJERCICIO DE LA JURISDICCIÓN CONTRA BUQUES SOSPECHOS DE TRATA DE PERSONAS Y TRÁFICO ILEGAL DE MIGRANTES}

Fernando Alfaro Martínez

Investigador del Master de Estudios Europeos y Derechos Humanos, Universidad Católica de San Antonio de Murcia. E-mail: falfaro@alu.ucam.edu

Convidado

\begin{abstract}
Analysis of the results of EUNAVFOR MED Operation Sophia since the beginning of its activities in June 2015, aiming to assert the level of achievement of its goals and conclude whether the establishment of a military operation was the best option to tackle a humanitarian crisis, as well as what have been the outcomes of the Operation for migrant mobility and for the actors involved, in particular, to the European solidarity system. The overview of the data presented by EUNAVFOR MED Operation Sophia helps to draw considerations for the future of the EU when dealing with future similar crises, not only affecting Europe, but in any country taking in consideration the migratory exodus happening, for example in South America these days, and that may be extended internationally. Is in this cases, where people flee from their origin countries seeking for shelter, when we must be aware of the necessary guarantee of Human Rights.
\end{abstract}

Keywords: Human Rights. Migration. European Union. EUNAVFOR MED Operation Sophia. Military interventions.

RESUMEN: Análisis de los resultados de la Operación EUNAVFOR MED Sofía desde el inicio de su actividad en junio de 2015, con el fin de determinar el grado de cumplimiento de sus objetivos. Se pretende arrojar luz sobre la necesidad de una operación militar con el objeto de paliar los efectos propios de una crisis humanitaria. Igualmente se analizan cuáles han sido las consecuencias tanto para los flujos de migración como para los actores involucrados, en particular, en el sistema de solidaridad europeo. Se presentan igualmente conclusiones derivadas del análisis de EUNAVFOR MED Sofía, y consideraciones a tener en cuenta para poder hacer frente a futuras crisis similares, no solamente en el marco de la Unión Europea, sino en otros países, a la vista de los éxodos migratorios que se vienen produciendo, especialmente en Sudamérica en la actualidad, y que se extenderán a nivel internacional. En estas realidades debemos ser, más que nunca, consecuentes de la necesaria garantía y protección de los Derechos Humanos.

Palabras clave: Derechos Humanos. Migración. Unión Europea. EUNAVFOR MED Operación Sofía. Intervenciones militares.

INDEX: Introduction. 1. Operation Sophia - 1.1 Critiques - 1.1.1 Regarding the Purpose of the Operation - 1.1.1.1 A Military Operation to Deal with a Humanitarian Crisis - 1.1.1.2 Externalization of the EU's Borders in order to Reduce Migration - 1.1.2. Regarding the Progress of the Operation - 1.1.2.1 Operation Sophia Addresses the Symptoms of the Migration Crisis, but not the Roots - 1.1.2.2 Operation Sophia has Endangered Migrants - 1.2 Achievements - 1.2.1 
Disrupting the Smugglers and Traffickers Business Model - 1.2.2 Preventing Loss of Life at Sea - 1.2.3 Operation Sophia v Operation Atalanta and Operation Mare Nostrum - 2. Realizations and Considerations for the Future since the Launch of Operation Sophia - 2.1 Lessons Learned: Enhancing the Comprehensive Approach - 2.1.1 The Need to Enable Legal and Safe Ways to Reach Europe - 2.1.2 The Need to Establish a Mechanism to Prosecute Suspected Smugglers and Traffickers - 2.2 Consequences and Considerations for the Future - 2.2.1 The Principle of Solidarity, at Hand - 2.2.2 Heading towards a Better CSDP Integration? - References.

\section{INTRODUCTION}

EUNAVFOR MED (EU Naval Force in the Mediterranean) Sophia was established in May 2015 as a response to the humanitarian crisis in the Mediterranean Sea. The aim of the operation is the disruption of the business model of migrant smugglers and human traffickers in the Mediterranean, whose activities endangers migrants' lives and has caused several loss of life at sea at the gates of Europe. The launching of Operation Sophia is a landmark in the European Union's history, because it is the first time that a naval operation is coordinated within the EU framework, engaging in search and rescue activities. Nevertheless, it is not the first time the EU launches a military operation to tackle a humanitarian crisis, as EUNAVFOR MED Atalanta had been launched in 2008 to help protect the ships involved in the transport and delivery of humanitarian aid to Somalia. A naval operation was already conducted by the Italian government in 2013, under the name of Operation Mare Nostrum, with a similar mandate. However, Operation Sophia is the first military operation coordinated by the EU's institutions, aimed at tackling a humanitarian crisis.

After a new tragedy occurred in the central Mediterranean on 20 April 2015, when a shipwreck meant around 800 deaths of migrants departing from Libya, ${ }^{1}$ the European Union declared "war" against migrant smugglers. The European Council concluded that it would "mobilise all efforts at its disposal to prevent further loss of life at sea", to fight the traffickers, prevent illegal migration flows and to reinforce internal solidarity and responsibility. ${ }^{2}$ Following this, the European Commission and the High Representative of the Union for Foreign Affairs and Security Policy presented the European Agenda on Migration, as a part of the comprehensive approach to tackle the crisis. Among this measures, EUNAVFOR MED were to be designed to identify the criminal networks, as well as to proceed with arrests and search and rescue operations, in cooperation with other EU agencies, such as the European Border and Coast Guard Agency (Frontex), or Europol.

According to Article 42(1) of the Treaty on the European Union, the Common Security and Defence Policy (CSDP) vests the European Union with the operational capacity to establish military and civil missions outside the territory of the Union for peace-keeping, conflict prevention and international security. The CSDP is an integrated part of the Common Foreign and Security Policy (CFSP), introduced by the Maastricht Treaty, which allowed the EU to develop a foreign policy and to have a unique voice, represented by European External Action Service. Decisions on CSDP are made unanimously by the Member States (MS) in the European Council. On 18 May 2015, Council Decision (CFSP) 2015/778 on a European Union military operation in the Southern Central Mediterranean (EUNAVFOR MED) was adopted. ${ }^{3}$ The aim of

\footnotetext{
${ }^{1}$ See Bonomolo A., Kirchgaessner S. (2015, April 20). UN says 800 migrants dead in boat disaster as Italy launches rescue of two more vessels. The Guardian. Retrieved from https://www.theguardian.com/world/2015/apr/20/italypm-matteo-renzi-migrant-shipwreck-crisis-srebrenica-massacre.

${ }^{2}$ European Commission, Europe is declaring war on smugglers, Remarks by Commissioner Avramopoulos at the press conference in Castille Place, Malta, 23 April 2015.

${ }^{3}$ European Union: Council of the European Union. Council Decision 2015/778 of 18 May 2015 on a European Union military operation in the Southern Central Mediterranean (EUNAVFOR MED). 19 May 2015. O.J. L122/31.

Revista de Direito Brasileira | São Paulo, SP | v. 20 | n. 8 | p. 19-42 |Mai./Ar. 2018
} 
EUNAVFOR MED was to identify, capture, and dispose of vessels and assets used or suspected of being used by migrant smugglers or traffickers, achieving a disruption of their business model, and thus preventing further loss of life at sea.

Article 1 of Council Decision (CFSP) 2015/778 states that "the Union shall conduct a military crisis management operation contributing to the disruption of the business model of human smuggling and trafficking networks in the Southern Central Mediterranean, achieved by undertaking systematic efforts to identify, capture and dispose of vessels and assets used or being used by smugglers or traffickers, in accordance with applicable international law".

The naval operation was structured in three sequential phases: in the first phase, conducted between June and October 2015, the naval assets Sophia supported the detection and monitoring of migration networks by patrolling on the high seas and gathering information. Since 7 October 2015, the operation has been in Phase 2, in which the naval operation conduct boarding, search, seizure, and diversion of vessels suspected of being used for human smuggling or trafficking, under the conditions laid down by international law, including the United Nations Convention on the Law of the Sea, an the Protocol against the Smuggling of Migrants. In Phase 2B, in accordance with any applicable UNSC Resolution or consent by the coastal state (Libya), Sophia shall conduct boarding, search, seizure, and diversion, on the high seas or in territorial and internal waters of the state, of vessels suspected of being used for human smuggling or trafficking. In the third and final phase, the naval operation shall take all necessary measures against a vessel and related assets, including disposal and confiscation, if they are suspected of being used for human smuggling or trafficking, again, in accordance with any applicable UNSC Resolution or consent by Libya. The Council of the EU, by its Decision (CFSP) 2016/993 of 20 June 2016, amended its previous Decisions by adding two supporting tasks to Operation Sophia: capacity building and training of the Libyan Coast Guard, and contribution to the implementation of the UN arms embargo on the high seas off the coast of Libya. ${ }^{4}$

The required United Nations Security Council's support came a few months after Operation Sophia was established, but it was only a partial measure. On 9 October 2015 the UNSC adopted Resolution 2240 by which, acting under Chapter VII of the Charter of the UN, authorized Member States to use all measures in confronting migrant smugglers or human traffickers in full compliance with international human rights law. ${ }^{5}$ The Resolution authorized the inspection on the high seas off the coast of Libya of suspect vessels of being used for migrant smuggling and human trafficking from Libya. The time was authorized for one year, from 18 May 2015 to 18 May 2016. Later on, the UNSC extended this authorization for three more periods of one year, until summer 2019.

\section{OPERATION SOPHIA}

EUNAVFOR MED has been subject to several analyses and criticisms. Given the relevance of the crisis the Operation has to deal with, the implications of its activities and the very nature of the European Union, Operation Sophia is under the scope of several institutions, political, military or academic. One of the roughest critical voices with the Operation has been the UK House of Lords, which in July 2017 published its second report on EUNAVFOR MED, and called it "Operation Sophia: a failed mission". 6

\footnotetext{
${ }^{4}$ For the UN arms embargo, see United Nations Security Council, Resolution 2292 (2016), on the situation In Libya, of 14 June 2016, S/RES/2292(2016).

${ }^{5}$ United Nations Security Council, Resolution 2240 (2015) on migrant smuggling and human trafficking into, through and from the Libyan territory. 9 October 2015, S/RES/2240 (2015).

${ }^{6}$ House of Lords (2017), Operation Sophia, a failed mission, European Union Committee, $2^{\text {nd }}$ Report of Session 2017-2019, retrieved from https://publications.parliament.uk/pa/ld201719/ldselect/ldeucom/5/5.pdf 
During its almost three years of activity, the naval operation has raised many concerns, mainly regarding refugee law or Human Rights law, but also the very intentions behind the European Union's main actors when deciding to launch a military operation to tackle the Central Mediterranean crisis. Proceedings carried out and the coordination with the other EU Agencies involved have been also put at stake, and finally, some have questioned the efficacy of Operation Sophia, or even argued that it hasn't been helpful at all.

From the Human Rights law perspective, while some argue that the EU should establish legal ways to reach Europe in a safe manner, others say that engaging in Search and Rescue activities only helps to produce a "pulling effect" on migrants. ${ }^{7}$ The cooperation with the Libyan authorities is not regarded as having been successful, as reports indicate that the Libyan Coast Guard keeps endangering migrants, but also critical voices argue that training the LCG is only aimed at reducing migration to the EU, in what it's called an externalization of the EU borders. ${ }^{8}$

As from the operational point of view, it has been argued that Operation Sophia will never be able to achieve its goal of disrupting the business model of migrant smugglers and human traffickers, as it has been aiming toward the symptoms of the problem, rather than to the roots. This is, lacking authorization to enter Libyan territory, so only low targets can be arrested. In addition, the EU has failed by not establishing a defined mechanism on how the arrests and prosecutions should be carried out, as the military task force lacks the capacities and jurisdiction required. Only Italy has prosecuted the suspected migrant smugglers and human traffickers arrested by Operation Sophia.

Lastly, the very efficacy of EUNAVFOR MED is questioned by some, regarding the prevention of further deaths at sea, which has been the main goal of the Operation. Critics argue that the number of deaths at sea have not decreased over the years, which might be true, but a bigger picture is necessary in order to address this issue: total migrants flow vary according to several factors and it's not dependent on the presence of a naval force in the route. A bigger flow of migrants means a bigger number of people endangered. In consequence, total flows of migrants have to be considered together with the amount of deaths. Since the establishment of Operation Sophia, significant achievements have been reached in this regard. According to the UN High Commissioner for Refugees, Filippo Grandi, the number of deaths at sea "would have been significantly higher had it not been for the Search and Rescue operations carried out". 9

The migration crisis, nevertheless, has not only affected the European Union regarding security matters. The European Union policy-making and basic principles have been also challenged due to the huge amount of migrants reaching the Union and the debate on how Member States should act. ${ }^{10}$ European migration policy has advanced since 2015 with the adoption of the European Agenda on Migration. ${ }^{11}$

\footnotetext{
${ }^{7}$ Dearden, L., (2017, June 9). Refugee rescue ships not acting as 'pull factor' or 'colluding with people smugglers', report finds. Independent. Retrieved from https://www.independent.co.uk/news/world/europe/refugee-crisis-europerescue-boats-ngos-pull-factor-collusion-smugglers-report-debunked-goldmiths-a7782781.html

${ }^{8}$ Baczynska, G. (2018, July 8). EU migration policies seen building blocks for 'Fortress Europe', Reuters. Retrieved from https://uk.reuters.com/article/uk-europe-migrants-analysis/eu-migration-policies-seen-building-blocks-forfortress-europe-idUKKBN1JY07V

${ }^{9}$ Grandi, F. (2016). Speech by Filippo Grandi, United Nations High Commissioner for Refugees, at the European Policy Centre, Brussels 5/12-2016. Available at http://www.unhcr.org/admin/58456ec34/protecting-refugees-europebeyond-eu-rise-challenge.html

10 European Commission. (July 2017). The EU and the Migration Crisis. Retrieved from http://publications.europa.eu/webpub/com/factsheets/migration-crisis/en/

${ }_{11}$ European Commission, Communication from the Commission to the European Parliament, the Council, the European Economic and Social Committee and the Committee of the Regions. A European Agenda of Migration, 13 May 2015, COM(2015) 240 final.
}

Revista de Direito Brasileira | São Paulo, SP | v. 20 | n. 8 | p. 19-42 |Mai./Ar. 2018 
Over the last three years, steps have been taken by the European Union covering various ranges of politics. Agreements of relocation have been signed, borders have been reinforced, ${ }^{12}$ and humanitarian and development funds have been granted, as the comprehensive approach to migration requires. The European Union Trust Fund for Syria received $€ 0.6$ billion from 2015 to 2017, and $€ 2.4$ billion were assigned to the Emergency Trust Fund for Africa. Also, the EU's funds that help migrants in countries like Jordan, Lebanon or Turkey, were $€ 1.6$ billion as assigned.

Dealing with migration inside the EU territory has proven to be quite more challenging, where the main political actors are facing a two-folded case, as migration became the top priority concern across the bloc, and different political groups are facing the challenge in different ways. First, countries like Hungary, Czech Republic, Slovakia and Poland, which have refused to take in asylum-seekers, represent one side of the coin, putting at stake the very foundational grounds of European integration, i.e. the principle of solidarity. ${ }^{13}$ Also, financial strains plus concerns over national security and cultural assimilation have encouraged the growth of far-right-antiimmigrant parties. Other countries like Germany, France, and Spain, represent the approach based on solidarity and responsibility among Member States, and backing sanctions against countries that don't want to deliver with their commitment. ${ }^{14}$

It is apparent that the migratory crisis will have a lasting effect in European politics and integration. Many agree that Europe needs to urgently overhaul its asylum and immigration rules. While some push for tougher border control, others seek a fairer distribution on new arrivals.

\subsection{CRITIQUES}

\subsubsection{Regarding the Purpose of the Operation}

\subsubsection{A Military Operation to Deal with a Humanitarian Crisis}

The response given by the European Union, launching a military operation to prevent loss of life at sea, could be seen as the militarization of a humanitarian crisis by an Operation authorized to use coercive force under Chapter VII of the UN Charter, and the criminalization of migrants, who are not other but endangered people. ${ }^{15}$ In fact, this reasoning makes a point: if Operation Sophia was launched to help refugees in distress at sea, in line with the humanitarian foreign policy model, it's to be expected that the Operation is established and conducted as a search and rescue operation, which must be the main priority of its task force. Furthermore, some authors say that, when deciding how to launch Operation Sophia, it was clear that the Operation would never be able to successfully advance into Phase $2 \mathrm{~B},{ }^{16}$ which is the core of the "disruption of the smugglers and traffickers business model" part of its mandate.

\footnotetext{
${ }^{12}$ European Commission. (2016, June 22) press release, European Border and Coast Guard agreed. (Press release). Retrieved from http://europa.eu/rapid/press-release_IP-16-2292_en.htm

${ }^{13}$ Article 80 of the Treaty on the Functioning of the European Union: The policies of the Union set out in this chapter shall be governed by the principle of solidarity and fair share of responsibility. European Union: Consolidated version of the Treaty on the Functioning of the European Union, 13 December 2007. O.J. C326/01, 26 October 2012.

14 Henley, J. (2018, June 27). EU migration crisis: what are the key issues? The Guardian. https://www.theguardian.com/world/2018/jun/27/eu-migration-crisis-what-are-the-issues

15 Arenas, N. (2016). Flujos masivos de población y seguridad. La crisis de personas refugiadas en el Mediterráneo, Araucaria, Revista Iberoamericana de Filosofía, Política y Humanidades. p. 368, and pp 339-372.

${ }^{16}$ Ingemann Johansen, A., (2017), Assessing the European Union's Strategic Capacity: The Case of EUNAVFOR MED Operation Sophia. Journal on European Security. p.521, and pp. 507 - 526.
}

Revista de Direito Brasileira | São Paulo, SP | v. 20 | n. 8 | p. 19-42 |Mai./Ago. 2018 
But the way Operation Sophia has been conducted since 2015, both Operation Sophia's task force and the EU political leaders, has showed a big degree of adaptation to the reality of Operation Sophia turning to be a de facto search and rescue operation after smugglers and traffickers were pushed back to the Libyan shores. Furthermore, In this sense, Operation Sophia "has been ready and equipped to meet their commitments under the International Convention on Safety of Law at Sea and the UN Convention on Law of the Sea, to rescue people in distress, despite the potential costs of such an approach in terms of attracting more migrants". ${ }^{17}$ As Rear Admiral Enrico Credendino explained to the Italian Parliament, in light of the events, EUNAVFOR MED was launched in record time. ${ }^{18}$

\subsubsection{Externalization of the EU's Borders in order to Reduce Migration}

In the same line, other authorities question the aim behind the EU when launching EUNAVFOR MED, arguing that what the European leaders were looking to block migration to the Union, setting up a military task force whose aim was not to rescue people, as it was, for example, Operation Mare Nostrum's. According to this, the European Union would be "obstructing individual's access to international protection", ${ }^{19}$ and blocking a migration route alleging to prevent shipwrecks. ${ }^{20}$ The reason behind this alleged intention would be the unwillingness of the EU leaders to take a decisive approach to the refugee crisis due to the many concerns migration is raising along Europe in terms of national security and cultural assimilation. $^{21}$ This view of the externalization of the EU's borders is supported by the overall image of the European Union presence in Africa, where its civil missions and military operations seem to have moved the EU borders towards the Sahel. It is true is that various political figures along the EU have claimed that such operations at sea would foster the "pulling effect", meaning that smugglers and traffickers, in the view that migrants are being rescued at sea, would be enhanced to keep with their illegal activities, and thus has sent more people to Europe. For example, German Interior Minister, Thomas de Maizière, said regarding Operation Mare Nostrum that it "proved to be a bridge to Europe". Finally, others have criticized that the EU political leaders did not establish in any resolution how the non-refoulement principle was to be made effective, or how Operation Sophia would help to request asylum in the EU upon arrival. ${ }^{22}$

\subsubsection{Regarding the Progress of the Operation}

\subsubsection{Operation Sophia Addresses the Symptoms of the Migration Crisis, but not the Roots}

In his six months report, the Commander of Operation Sophia already emphasised that, in order to be really effective against the smugglers' business model, transition to Phase $2 \mathrm{~B}$ had

\footnotetext{
17 Riddervold, M., The Maritime turn in EU Foreign and Security Policies. Aims, Actors and Mechanisms of Integration, Palgrave MacMillan, ed 1 (2017), Switzerland. p. 69.

18 Senato della Repubblica. (2016). Audizione dell' ammiraglio di divisione Enrico Credendino, Operation Commander della operatione EUNAVFOR MED - Operazione Sophia. $18^{\text {a }}$ seduta, 4 febbraio, AU 0683. Roma: Senato della Repubblica.

${ }^{19}$ Garelli, G., Tazzioli M., The Humanitarian War Against Migrant Smugglers at Sea, Forthcoming, Antipode, Volume 50(3) 'Mediterranean Movements: Mobility Struggles, Border Restructuring, and The Humanitarian Frontier'), 2015, p. 690, and pp. 685-703.

${ }^{20}$ Ventrella, M (2016), The impact of Operation Sophia on the exercise of criminal jurisdiction against migrant smugglers and human traffickers. Questions of International Law, Volume 30, p. 16, and pp. 3 - 18.

${ }^{21}$ Berry, M., Garcia-Blanco, I., \& Moore, K. (2016). Press coverage of the refugee and migrant crisis in the EU: A content analysis of five European countries. Project report. Geneva: United Nations High Commissioner for Refugees. Retrieved from http://www.unhcr.org/56bb369c9.html

${ }^{22}$ Arenas, N. (2016), Flujos masivos de población y seguridad. La crisis de personas refugiadas en el Mediterráneo, p. 353. Supra note.
}

Revista de Direito Brasileira | São Paulo, SP | v. 20 | n. 8 | p. 19-42 |Mai./Ar. 2018 
to be done as soon as possible. ${ }^{23}$ Noting that the report is dated from December 2017, we can conclude that no great progress has been made on the disruption of the smugglers' business model. In fact, even though EUNAVFOR MED has contributed to the arrest of 148 suspected criminals to date, the majority of them have been low targets. ${ }^{24}$ Also, when the naval assets of the Operation started patrolling on the high seas, and the smugglers and traffickers were pushed back to Libya, Operation Sophia reduced its activities to mainly the search and rescue: note that from June 2017 to June 2018, the number of suspected smugglers or traffickers arrested were only $39 .{ }^{25}$

As a result, the very impact on the smuggling networks is questioned: if you only tackle the criminals at the bottom, who are easily replaced, the business model will not be affected, since the data you can gather is not enough to get to the command of these mafias. Apart from this, even if Operation Sophia were able to identify the criminals at the top of the organizations, further actions would be simply impossible, as there is no UNSC authorization to access the Libyan territorial waters and inland, nor is there Libyan consent.

Furthermore, migration from Libya is not a consequence of the mafias' activities, but of a greater picture of conflicts over Africa and the Middle-East, of which migrants are running away. If Operation Sophia were successful, this does not mean that migration would be stopped, but only that the Libyan route could be paralyzed for a certain period, with high possibilities that other migration routes in the Mediterranean would see its flows increasing. ${ }^{26}$

\subsubsection{Operation Sophia has Endangered Migrants}

Regarding migrants endangered as a consequence of EUNAVFOR MED's activities, two main points emerge: the destruction of the vessels employed by the mafias to ferry migrants to the EU, and the Memorandum of Understanding signed with the Libyan authorities for training and capacity building of the Libyan Coastguard.

Destroying the vessels used for ferrying people across the Mediterranean is supposed to prevent shipwrecks. Nevertheless, migrant smugglers and human traffickers adapted their business model, and the safer fiber-glass boats were no longer used, representing a financial loss after destructed. Instead, rubber dinghies started being used, having less capacity and more limited conditions, and used to carry equal amounts of people. ${ }^{27}$

The Memorandum of Understanding with the Libyan authorities has been criticized by different institutions due to the dire human rights situation that persists in Libya today. In addition, there has been several alarming news about several of the LCG's activities. As an example, in May 2017, the LCG opened fire on Europe-bound boats full of refugees while rescue

\footnotetext{
${ }^{23}$ WikiLeaks. (2016). EUNAVFOR MED Op Sophia (2016) - Six Monthly Report 22 June-31 December 2015. p.19. Retrieved from https://wikileaks.org/eu-military-refugees/EEAS/EEAS-2016-126.pdf

${ }^{24}$ House of Lords (2017), Operation Sophia, a failed mission, p.7. Supra note.

25 A factsheet released by the EEAS in April 2017 mentioned 109 suspected smugglers apprehended, while the factsheet released on June 2018 by the European Commission says the total suspects apprehended is 148 . See European External Action Service. (2015, April 25). EUNAVFOR MED, MISSION. Retrieved from https://eeas.europa.eu/sites/eeas/files/april_2017_-_factsheet_on_eunavfor_med_mission_english.pdf, and European Commission. (2018, June 26). Central Mediterranean Route: Protecting Migrants and Managing Irregular Flows. (Press release). Retrieved from https://eeas.europa.eu/sites/eeas/files/central_med_route_v6.pdf

${ }^{26}$ Tardy, T., (2015), Operation Sophia. Tackling the refugee crisis with military means, European Union Institute for $\begin{array}{llllll}\text { Security Studies, } & \text { Sep } & \text { 2015, retrieved from }\end{array}$ https://www.iss.europa.eu/sites/default/files/EUISSFiles/Brief_30_Operation_Sophia.pdf

${ }^{27}$ House of Lords (2016), Operation Sophia, the EU's naval mission in the Mediterranean: an imposible challenge, European Union Committee, 14th Report of Session 2015-16, p.16, retrieved from https://publications.parliament.uk/pa/ld201516/ldselect/ldeucom/144/144.pdf Revista de Direito Brasileira | São Paulo, SP | v. 20 | n. 8 | p. 19-42 |Mai./Ago. 2018
} 
attempts were under way. ${ }^{28}$ Reports on beatings by officials of the LCG, as well as rape, torture and killings still skyrocketing, ${ }^{29}$ in what is considered to be a failure of the training program, which has not been able to achieve a swift end in this trend.

After all, the endangerment of migrants is not a direct responsibility of Operation Sophia, nor of its training program. Since the naval assets cannot access the Libyan territory, it is seemingly to be a good idea to develop the capacities of those who deal with migrants there. Critics do not consider that given the situation in the country, and knowing that officials of the LCG collaborate with the mafia or militia, progress is only to be achieved slowly, and will eventually depend on the overall situation of the country. It is assumed at this stage that Libyan personnel is not trained by the members of Operation Sophia to pursue such purposes by means contrary to international and human rights law.

Additionally, some argue that the training of the LCG aims at developing the capacity of Libya to better control it's coastal and territorial waters, relieving the EU of doing this job, and aiming to curve migration to the Union. Enhancing the Libyan capacity to prevent those fleeing ill-treatment in Libya from reaching international waters and bringing them back to shore can be considered an assistance to the commission by Libya of internationally wrongful acts or in the maintenance of the illegal situation in Libya. According to this, the EU training could be considered to be aiding Libya in a policy of refoulement, then being the EU engaged in the socalled refoulement by proxy. ${ }^{30}$ As of 31 May 2018, 42\% of migrants departing from Libya were pushed back, while in the same period in 2017 , the proportion was $11 \%{ }^{31}$ Those who were brought back to Libya would most likely face ill-treatment once again. It appears that the issue is whether the EU training constitutes aid or assistance in the commission on internationally wrongful acts by the Libyan authorities.

Under the rules of international responsibility, codified by the International Law Commission, "a State which aids or assists another State in the commission of an internationally wrongful act by the latter is internationally responsible" if that State does so with knowledge of the circumstances, and the act would be internationally wrongful if committed by that State. ${ }^{32}$

It seems unlikely that the training provided by EUNAVFOR MED to the LCG can be said to direct and control Libya to commit internationally wrongful acts. Since the purpose of the training of the Libyan officials is not aiming at the commission of any wrongful act, but based on human rights law, it can be concluded that no commission nor assistance is provided by the EU when the LCG commits internationally wrongful acts. Furthermore, the refoulement by proxy accusations lack an important fact: Non-Refoulement requires that a person is transferred, returned or extradited "to another State". ${ }^{33}$ So, when Libyan authorities arrest migrants in their own territory or on the high seas and bring them back to Libya, no refoulement occurs.

Actually, it can be stated that, provided the lack of authorization or consent to enter the Libyan territorial waters and inland, what the EU does by training the Libyan authorities could be

28 Elaradi, H. (2017, July 31). The failure of Libya's EU-Backed Coastguard, Atlantic Council http://www.atlanticcouncil.org/blogs/menasource/the-failure-of-libya-s-eu-backed-coastguard

29 The Guardian, EU's policy of helping Libya intercept migrants is 'inhuman', says UN, 2017. Retrieved from https://www.theguardian.com/world/2017/nov/14/eu-libya-coastguard-detention-centres-migration-mediterraneanun-zeid-raad-al-hussein

${ }^{30}$ D'Argent, P., Kuritzky, M., (2017), Refoulement by proxy? The Mediterranean migrant crisis and the training of Libyan Coast Guard by EUNAVFO MED Operation Sophia, Israel Yearbook on Human Rights, Volume 47 (2017), p.259, and pp. $233-264$.

${ }^{31}$ Clarke, L. (2018, June 28). In the hands of the Libyan Coast Guard: pushbacks by proxy. Open Migration. Retrieved from https://openmigration.org/en/analyses/in-the-hands-of-the-libyan-coast-guard-pushbacks-by-proxy/

${ }^{32}$ United Nations General Assembly, Responsibility for States for internationally wrongful acts, Art 16. 28 Jan 2002, A/RES/56/83.

${ }^{33}$ UN General Assembly, Convention Against Torture and Other Cruel, Inhuman or Degrading Treatment or Punishment, 10 December 1984, United Nations, Treaty Series, Vol. 1465, p. 85. Available at https://www.ohchr.org/en/professionalinterest/pages/cat.aspx

Revista de Direito Brasileira | São Paulo, SP | v. 20 | n. 8 | p. 19-42 |Mai./Ar. 2018 
in furtherance of a duty to prevent abuses, ${ }^{34}$ in furtherance of Article 41 of the 2001 Articles on Responsibility of States for Internationally Wrongful Acts, that reads: "States shall cooperate to bring to an end through lawful means any serious breach". 35

\subsection{ACHIEVEMENTS}

EUNAVFOR MED activities since its establishment in 2015 have been subject to diverse criticism, not only for its failure to act (tackling smugglers and traffickers' businesses) but also on the achievement of its goals, which are regarded to be insufficient or even counterproductive. But, in order to determine whether an operation can be considered a success, it is necessary to identify the level of accomplishment of its goals. This means that an operation is successful when its purpose has been achieved and implemented in an appropriate manner from both the EU and a conflict perspective. ${ }^{36}$

According to Council Decision (CFSP) 2015/778, Operation Sophia's mandate is the disruption of the business model of smugglers and traffickers. Given the narrowness of the mandate and the imperative of rescuing people in distress at sea, saving lives turns to be an immediate objective of Operation Sophia as well.

Given these two objectives, how can the degree of success be assessed? If the mission is successful, we can argue that networks' ability to bring migrants into international waters would be curtailed from the Libyan shores at least for a certain period of time. ${ }^{37}$ This doesn't mean that the migrants would disappear or that all of the smugglers and traffickers would be neutralised. So, a successful operation should have resulted in a reduction of flows and the arrest of criminals. Regarding this, a very important factor needs to be considered: as Operation Sophia advanced into territorial waters, smugglers and traffickers moved back to Libya, where no action could be taken. Consequently, the success of Operation Sophia in disrupting the smugglers and traffickers business must only be considered on the range of action that EUNAVFOR MED has had, which is really difficult to calculate.

\footnotetext{
${ }^{34}$ D'Argent, P., Kuritzky, M. (2017). Refoulement by proxy? The Mediterranean migrant crisis and the training of Libyan Coast Guard by EUNAVFO MED Operation Sophia. Supra note. p. 263.

${ }^{35}$ International Law Commission, Draft Articles on Responsibility of States for Internationally Wrongful Acts. November 2001, Supplement No. $10 \quad$ (A/56/10), chp. I.V.E.1. Available at https://www.law.umich.edu/facultyhome/drwcasebook/Documents/Documents/International\%20Law\%20Commissio n\%202001\%20Draft\%20Articles\%20on\%20State\%20Responsibility.pdf

${ }^{36}$ Peen Rodt, A. (2012). EU performance in military conflict management. In The European Union as a Global Conflict Manager. New York. ed. by Richard G. Whitman, and Stefan Wolff (Abingdon Routledge, 2012). pp. 169183.

${ }^{37}$ Tardy, T., (2015), Operation Sophia. Tackling the refugee crisis with military means, European Union Institute for $\begin{array}{llllll}\text { Security Studies, } & \text { Sep } & 2015, & \text { retrieved from }\end{array}$ https://www.iss.europa.eu/sites/default/files/EUISSFiles/Brief_30_Operation_Sophia.pdf
} 


\subsubsection{Disrupting the Smugglers and Traffickers Business Model}

From October to December 2015, 46 suspected smugglers and traffickers were arrested. ${ }^{38}$ Dating to October 2016, just one year after engaging in active endeavour, Operation Sophia contributed to the arrest of 89 suspected smugglers and traffickers. ${ }^{39}$ As for April 2017, as mentioned, the number of criminals arrested was of 109, and by the end of June 2018, the total number was 148 suspected smugglers and traffickers arrested by Operation Sophia. What can be concluded by taking a look at the data is the confirmation of the before mentioned: criminals adapted their strategies and got out of the high seas as EUNAVFOR MED advanced toward them. In its first three months of activity, the naval assets contributed to the arrest of approximately the same amount of criminals as in the entire year 2016.

Furthermore, in order to deliver an exact assessment on the achievements of Operation Sophia in the arrest of criminals, further data is required, especially regarding the number of smugglers and traffickers involved in individual activities, to be fully aware of the relevance (or lack of it) of the arrests accomplished by EUNAVFOR MED. Unfortunately, this data is almost impossible to gather, as long as no action can be taken in Libya, where the criminals plan and proceed with their activities.

Finally, the conducted activities of data-gathering and networking together with other EU Agencies like Europol, Eurojust or Frontex are not published. Notice that Phase 1 of EUNAVFOR MED consisted on data gathering, which probably has been used by these Agencies to conduct arrests of smugglers and traffickers, thanks to the data collected by Operation Sophia. Data published on arrests conducted includes only those carried out directly by the naval assets under the direction of Rear Admiral Enrico Credendino.

\subsubsection{Preventing Loss of Life at Sea}

Analysing the outcome of the naval Operation regarding search and rescue activities, this means, saving migrants and asylum-seekers in distress at sea and thus preventing deaths, is quite easier. For that purpose, the comparison between the total flow of migrants in the Central Mediterranean route in a fixed period and the amount of deaths in the same route for the same period, can give a good overview of the outcomes of the several actors (military operations and NGOs mainly) in search and rescue activities. In addition, total amount of rescued people by the naval assets of Operation Sophia, together is to be considered.

As the data from International Organization for Migration (IOM) shows, the death rate for the Central Mediterranean route has been always lower since Operation Sophia was launched, compared to the previous data: From January to October 2015 the death rate was of $6.3 \%$, while from October to December 2015, the death rate lowered to $2.51 \%$. The death rates over 2016 and 2017 has been of $2.52 \%$ and $2.38 \%$ respectively. ${ }^{40}$ As data shows, the percentage of people who drowned or disappeared at sea in their attempts to reach European shores declined dramatically after the deployment of naval forces (deaths over the total flow of migrants in the Central Mediterranean route).

Since the beginning of EUNAVFOR MED's activities, more than 44,000 lives have been saved at sea following search and rescue activities. The total people saved at sea of

\footnotetext{
${ }^{38}$ WikiLeaks. (2016). EUNAVFOR MED Op Sophia (2016) - Six Monthly Report 22 June-31 December 2015. p. 3. Supra note.

39 European Commission. (2016, October 4). EU Operations in the Mediterranean. Available at https:/ec.europa.eu/home-affairs/sites/homeaffairs/files/what-we-do/policies/securing-eu-borders/factsheets/docs/20161006/eu_operations_in_the_mediterranean_sea_en.pdf.

${ }^{40}$ International Organization for Migration. (updated 2018, September 17). Missing Migrants Project. Tracking deaths along migratory routes. Central Mediterranean. Retrieved from https://missingmigrants.iom.int/region/mediterranean?migrant_route\%5B $\% 5 \mathrm{D}=1376$
}

Revista de Direito Brasileira | São Paulo, SP | v. 20 | n. 8 | p. 19-42 |Mai./Ar. 2018 
Operation Sophia together with Frontex's Joint Operation Triton reaches 290,000 lives. Conclusions do differ, ${ }^{41}$ but from this analysis we can conclude that Operation Sophia has been a "humanitarian success". 42

Operation Triton and Operation Sophia covered areas

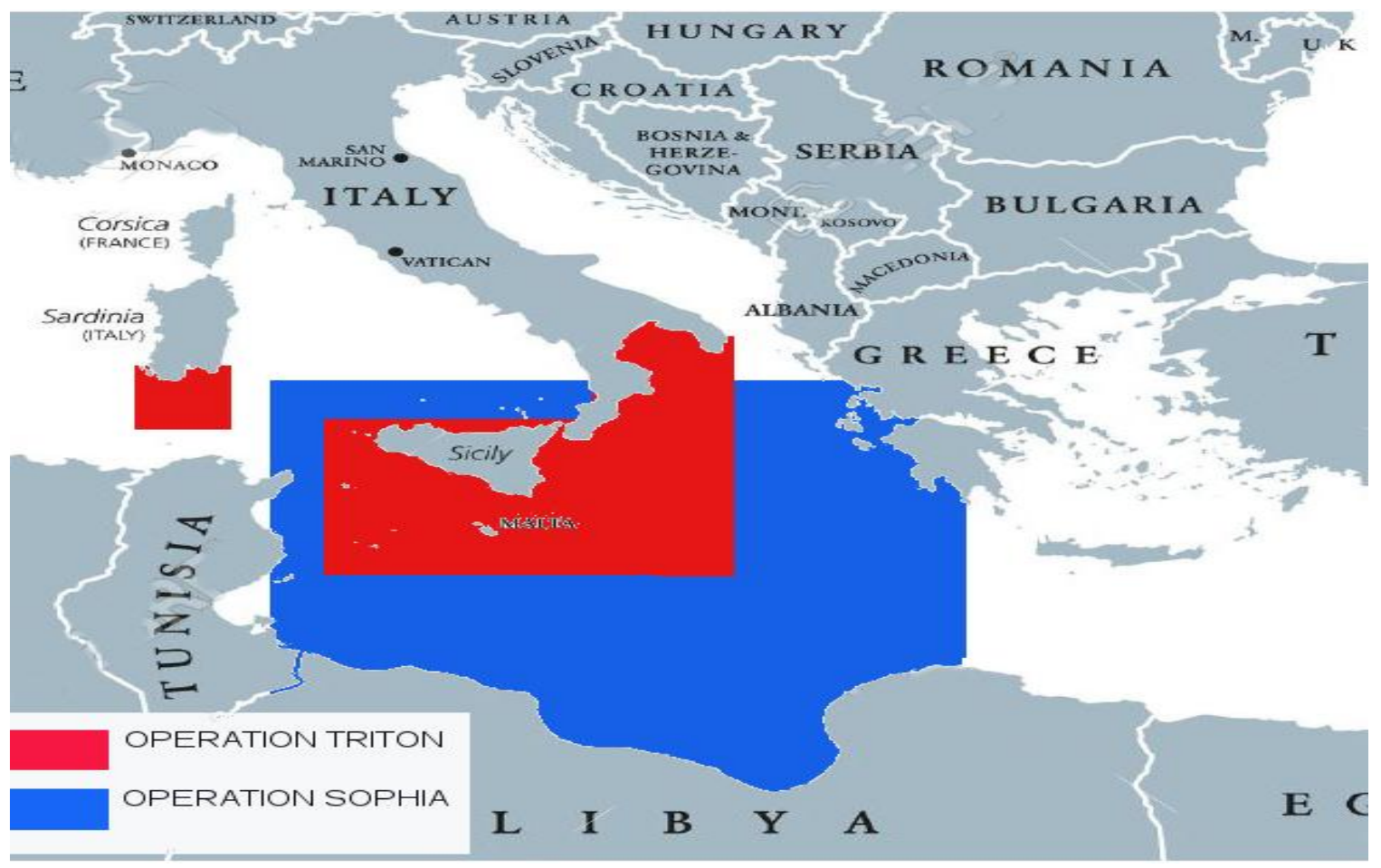

\subsubsection{Operation Sophia $v$ Operation Atalanta and Operation Mare Nostrum}

Assessment of the achievements of EUNAVFOR MED must be completed by comparing it's outcomes with other operations. Clarification on how successful Operation Sophia has been on tackling the smugglers and traffickers business can be helped through comparison with EUNAVFOR Operation Atalanta. As for the search and rescue outcomes of Operation Sophia, comparison with people rescued by Italy's Operation Mare Nostrum is necessary.

EU Operation Atalanta has considerably helped in tackling piracy off the coast of Somalia. Taking a look at the number of total attacks, in 2009 there were 163, combining aborted attacks, hostages and ships held by pirates. ${ }^{43}$ By October 2016, the number dropped to no hostages and ships being held by pirates, with more than 160 pirates being transferred to competent authorities for prosecution. ${ }^{44}$ Since the beginning of Atalanta, all of the World Food Program vessels operating in Somali waters have achieved its tasks suffering no attacks from pirates. Extension to the land territory of Somalia was based on the UNSC Resolution

\footnotetext{
${ }^{41}$ Belgian migration minister describes the EU migrant rescue mission as 'pure lunacy' that is causing more deaths as he calls for Belgium's frigate to leave the Mediterranean. (2017, July 16). The Daily Mail. Retrieved from https:/www.libyaherald.com/2017/07/16/belgian-minister-says-operation-sophia-is-lunacy/

42 Bulman, M (2017, July 12). EU refugee anti-smuggling mission is driving deaths in the Mediterranean, finds report. The Independent. Retrieved from https://www.independent.co.uk/news/world/europe/eu-refugee-rescuemission-mediterranean-people-smuggling-north-africa-report-migrant-crisis-european-a 7835631.html

43 European External Action Service. EUNAVFOR SOMALIA. Countering Piracy off the Coast of Somalia. Retrieved from http://eunavfor.eu

${ }^{44}$ After an agreement signed with Kenya, suspected pirates are being prosecuted on that country. See European External Action Service. (2010, August 9). EU \& Kenya co-operate to prosecute pirates. Retrieved from http://eunavfor.eu/eu-kenya-co-operate-to-prosecute-pirates/
} 
1851/2008. ${ }^{45}$ What EUNAVFOR Atalanta has achieved on Somalia is considered, thus, as a whole success, given the complete reduction of piracy over the Somali coast, and the high level of accomplishment of the Operation's goal. Nevertheless, there is a difference between Atalanta and Sophia's ranges of action: while EUNAVFOR was granted permission to act on the coastal State's territory and territorial waters, EUNAVFOR MED hasn't yet. Furthermore, cooperation with Somali and Kenyan authorities granted detention and prosecution of suspected pirates in Somalia, while no agreement has been signed with Libya on that regard for Operation Sophia. It can be concluded that cooperation with the coastal State is the key point when comes to tackling illegal activities on its territory. We will have to wait for the eventual consent of Libya to deliver a complete analysis of Sophia's success rate.

On the other hand, Italy's emergency Operation Mare Nostrum rescued 156,362 migrants and asylum-seekers in $2014 .{ }^{46}$ This outnumbers by far the 44,000 people rescued by Operation Sophia in almost three years of activity. Even though Mare Nostrum's mandate was the engaging in search and rescue activities, ${ }^{47}$ and not Operation Sophia's. Yet, other factors must be considered: since 2015, more actors got involved in the Southern Central Mediterranean. Frontex's Joint Operation Triton began its activity in May 2015, and the very same month, various NGOs got involved as well, ${ }^{48}$ resulting in a shared distribution on search and rescue tasks that previously Mare Nostrum conducted by itself. According to an MSF's report, SAR operations during 2016 conducted 46,806 rescues on the high seas, 17\% of them by Operation Sophia, and $8 \%$ by Frontex. Can be concluded that the presence of more actively involved actors on the Central Mediterranean resulted in the distribution of the SAR activities.

In addition, it is to be recalled that Operation Sophia is an integrated part of the EU's comprehensive approach to migration. The EU's outcome on SAR activities involves participation of other Agencies like Frontex. From February 2016 to June 2018, the EU has rescued with the European Border and Coast Guard Agency and EUNAVFOR MED Operation Sophia more than 290,000 lives, ${ }^{49}$ confirming the EU's involvement as a humanitarian actor.

\section{REALIZATIONS AND CONSIDERATIONS FOR THE FUTURE SINCE THE LAUNCH OF OPERATION SOPHIA}

\subsection{LESSONS LEARNED: ENHANCING THE COMPREHENSIVE APPROACH}

\subsubsection{The Need to Enable Legal and Safe Ways to Reach Europe}

The only definitive way to tackle the business model of migrant smugglers and human traffickers is, as recognized by the European Council in June 2018 to prevent tragic loss of life at sea, to put an end to their need to embark on perilous journeys. ${ }^{50}$ Developing legal pathways to persons in need is a requirement of the comprehensive approach to migration, and it's the only

${ }^{45}$ United Nations Security Council, Security Council Resolution 1851 (2008), on the fight of piracy and armed robbery at sea off the coast of Somalia.16 December 2008. S/RES/1851 (2008).

${ }^{46}$ Statista, Number of rescued migrants with the Operation Mare Nostrum from 2005 to 2014 , in Italy. 2015. Retrieved from https:/www.statista.com/statistics/579418/number-ofrescued-migrants-operation-mare-nostrumitaly/

${ }^{47}$ Ministerio Della Difesa, Mare $\quad$ Nostrum http://www.marina.difesa.it/EN/operations/Pagine/MareNostrum.aspx. Accessed 17 Jul 2018.

${ }^{48}$ Humanitarian NGOs conducting Search and Rescue Operations at Sea: A “pull factor”? (August 2017). Médecins Sans Frontières. $\quad$ Issue $\quad$ brief. Retrieved from http://searchandrescue.msf.org/assets/uploads/files/170831_Analysis_SAR_Issue_Brief_Final.pdf

49 European Commission. (2018, June 26). Central Mediterranean Route: Protecting Migrants and Managing Irregular Flows. (Press release). Supra note.

${ }^{50}$ European Council. (2018, June 29). European Council conclusions, 28 June 2018. (Press release). Retrieved from http://www.consilium.europa.eu/en/press/press-releases/2018/06/29/20180628-euco-conclusions-final/

Revista de Direito Brasileira | São Paulo, SP | v. 20 | n. 8 | p. 19-42 |Mai./Ar. 2018 
way to tackle irregular flows. There is a wide range of measures that Member States could adopt in order to increase the possibilities for refugees and asylum-seekers to travel in a safe and legal way to EU territory. The most important ones include the issuance of humanitarian visas, a more flexible use of family reunification procedures, or the increase of resettlement places along the EU. ${ }^{51}$

Since the beginning of the migratory crisis in 2015, the EU's response has been varied, and always acting after alarming events taking place. The EU's temporary emergency scheme was decided in 2015 by the Council, in which Member States committed to relocate up to 160,000 people from Italy and Greece hotspots. ${ }^{52}$ Later on, the EU-Turkey joint action plan was adopted, under which Turkey would try to stop migratory flows to the EU, and offer safe ways for refugees to access the Union. ${ }^{53}$ The EU-Turkey joint action plan proved to be far from achieving its goals, and the European Council, on March 2016, called for an acceleration of the implementation of relocation. On July 2016, the European Commission proposed a permanent EU Resettlement Framework to establish a common set of standard procedures for the selection of resettlement candidates that has not been adopted yet. ${ }^{54}$

This legal and safe pathway to reach the European Union would require a major consensus of Member States and a strong commitment to the principles of responsibility and solidarity. According to the June 2018 European Council, a reform on the Dublin Regulation would be also required. ${ }^{55}$ Yet, in 2016, the European Commission drafted a proposal to reform the Common European Asylum System, the Dublin IV Regulation, providing a faster mechanism to deal with situations of disproportionate pressure on Member States' asylum systems. Nevertheless, the urgency of the current situation calls for further measures.

On his State of the Union Address on 12 September 2018, president of the European Commission, Jean-Claude Juncker, presented a new package of measures to better tackle migration, alleging that ad-hoc solutions cannot be the EU answer. According to Juncker, the European Commission will present three new proposals to ensure full EU solidarity on migration and protection of the EU's external borders: Enhancing legal and safe ways to reach Europe, the reinforcement of the European Border and Coast Guard Agency (Frontex), and the extension of the mandate of the European Asylum Support Office (EASO).

The European Commission called Member States to deliver on their commitment to resettle 50,000 persons by October 2019, and to agree on the Commission proposal for a Union Resettlement Framework on a fairer distribution on resettlement applications. ${ }^{56}$ So far approximately 40,000 people have been resettled since 2015. Establishing legal migratory routes

\footnotetext{
${ }^{51}$ Chetail, V. (2016). Reforming the Common European Asylum System: The New European Refugee Law. International Journal of Refugee Law, Volume 29 (2). p. 89.

${ }^{52}$ European Union: Council of the European Union, Council Decision (EU) 2015/1601 of 22 September 2015 establishing provisional measures in the area on international protection for the benefit of Italy and Greece. 24 September 2015, L 248/80. Available at https://eur-lex.europa.eu/legalcontent/EN/TXT/HTML/?uri=CELEX:32015D1601\&from=EN

${ }_{53}$ European Commission. (2015, October 15). EU-Turkey joint action plan. (Press release). Retrieved from http://europa.eu/rapid/press-release_MEMO-15-5860_en.htm

${ }^{54}$ European Commission. (2016, July 13). Proposal for a Regulation of the European Parliament and of the Council establishing a Union Resettlement Framework and amending Regulation (EU) No 516/2014 of the European Parliament and the Council. COM (2016) 468 final.

${ }^{55}$ The Dublin Regulation establishes the Member State responsible for the examination of the asylum applications. See European Union: Council of the European Union. Regulation (EU) No 604/2013 of the European Parliament and of the Council, of 26 June 2013, establishing the criteria and mechanisms for determining the Member State responsible for examining an application for international protection lodged in one of the Member States by a thirdcountry national or a stateless person. 29 June 2013. O.J. L. 180/31-180/59, (EU) No 604/2013.

${ }^{56}$ European Commission (2018, September 12). Communication from the Commission to the European Parliament and the Council. Enhancing legal pathways to Europe: an indispensable part of a balanced and comprehensive migration policy. Retrieved from https://ec.europa.eu/commission/sites/beta-political/files/soteu2018-legalpathways-europe-communication-635_en.pdf
} 
also requires, according to Juncker, the strengthening of cooperation with African countries of origin and transit. The European Commission confirmed pilot projects to be started at the end of 2018, in order to cooperate in the establishment on legal migration, including labour and traineeship agreements, and well as readmission and returns.

In order to reinforce the operational capability of Frontex, the European Commission announced that new staff, tools and financial means would help the Agency on its tasks of supporting Member States through the Asylum Procedure, as well as during the procedure under the Dublin Regulation. ${ }^{57}$ To achieve this goal, Frontex will increase its agents by 10,000 by the year 2020, being able to rely on its own staff. Frontex will deploy, after request by the Member States, migration management support teams, who will help assisting in identification and registration of asylum-seekers, providing logistical support and translation services, and preparing administrative decisions on applications for international protection. The Agency will be authorized to launch joint operations in order to patrol borders and intercept vessels. The intention behind this reinforcement of Frontex by the European Commission relies on the help the Agency could supply to Member States to better manage migratory waves.

The revised proposal for a European Union Agency for Asylum aims to establish a close link between the Agency and Frontex in the assistance to Member States where their asylum and reception systems are subject to pressure. ${ }^{58}$ As with Frontex, the European Commission aims to extend the mandate of the EASO into a full-fledged European Union Agency for Asylum, as well as its assets and operability. If the proposal is adopted, the Agency will be able to assist MS with identification and registration procedures, registration and examination of international protection applications, and to assist them with their obligations under the Dublin Regulation. The proposal states that the Agency will cooperate with Frontex, Europol and other EU Agencies, but doesn't specify how. ${ }^{59}$

\subsubsection{The Need to Establish a Mechanism to Prosecute Suspected Smugglers and Traffickers}

Another relevant aspect that Operation Sophia's activities pointed out, is the lack of a working mechanism to prosecute suspected migrant smugglers or human traffickers apprehended by its task force. It is obvious that, in order to carry out prosecution, the naval assets are not valid, and that police and judicial cooperation are required. So far, suspected criminals have only been prosecuted by Italy, because of the need of Italy to deal with the huge migratory flows on its territory, but neither Italy nor other EU Member State are compelled to carry out prosecution against mafias. Also, the way some procedures have been carried, such as interviewing migrants just upon arrival to ports, underlines the need to establish a coordinated mechanism at the EU level, as a part of the comprehensive approach.

Operation Sophia has contributed to the arrest of 148 suspected smugglers and traffickers by the end of June 2018. Nevertheless, Sophia is not a police operation. Only in 2016, Joint Operation Triton contributed to the arrest of 588 smugglers and traffickers. Nevertheless, arrests carried out by the naval forces are taken advantage of in order to interview migrants and

\footnotetext{
${ }^{57}$ European Commission. (2018, September 12). A strengthened and fully equipped European Border and Coast Guard. (Press release). Retrieved from https:/ec.europa.eu/commission/sites/beta-political/files/soteu2018-factsheetcoast-guard_en.pdf

${ }^{58}$ European Commission. (2018, September 12). Amended proposal for a Regulation on the European Union Agency for Asylum and Repealing Regulation (EU) No439/2010. COM(2018) 633 final. Available at https://ec.europa.eu/commission/sites/beta-political/files/soteu2018-eu-agency-asylum-regulation-633_en.pdf

${ }^{59}$ European Commission. (2018, September 12). State of the Union 2018: A reinforced European Union Agency for Asylum - Questions and Answers. (Press release). Retrieved from http://europa.eu/rapid/press-release_MEMO-185714_en.htm
} 
gain information about their journeys. ${ }^{60}$ Italian prosecutors receive information from the naval officers immediately after the embarkation of a ship. The activities conducted on board are then filed in a report and handed over to the Italian prosecutor, who is present whenever a ship arrives.

In addition, in the aftermath of concluded rescue operations, Frontex agents have interrogated migrants upon arrival, ${ }^{61}$ on what some call to be a process of "knowledge extraction" from migrants, turning them into informants about the mafias' activities, instead of integrating them as witnesses in a judicial procedure.

This is the key reason of why the European Union should coordinate effort to establish a completely defined prosecution scheme, but not the only one: transition into Phase $2 \mathrm{~B}$ would allow Operation Sophia to act against migrant smugglers and human traffickers on the Libyan inland and territorial waters, but not to transport them to the EU upon prosecution. A Libyan authorization would also be required for suspected criminals to be transferred for prosecution. ${ }^{62}$ The European Union main political actors have to face this twofold issue (on how to prosecute criminals on the EU and to reach transfer agreements with Libya) for the total disruption of the smugglers and traffickers business models.

It is obvious that the political situation in Libya is a key factor for the EU's goals, even regarding judicial cooperation. For now, the absence of smugglers in international waters caused Italian prosecutors to describe their current judicial procedures as a stalemate, ${ }^{63}$ and the same goes for the European Union itself.

It some authors' view that the consecution of prosecution and judiciary cooperation agreements along the EU would be enhanced by the establishment of the European Public Prosecutor's Office (EPPO). ${ }^{64}$ In June 2017, 20 EU Member States reached an agreement on the establishment of the EPPO under enhanced cooperation, which right now counts on 21 Member States. But the EPPO's tasks include only the prosecution of criminal offences affecting the financial interests of the Union. ${ }^{65}$ Nevertheless, the TFEU also states that the EPPO's scope can be extended "to include serious crime having cross-border dimension". ${ }^{66}$ It seems that the future of the EU's fight against migrant smugglers and human traffickers could be on the extended mandate of the EPPO, but now this seems far to be reached.

\subsection{CONSEQUENCES AND CONSIDERATIONS FOR THE FUTURE}

\subsubsection{The Principle of Solidarity, at Hand}

The migratory crisis starting in 2015 and the arrival of migrants and asylum-seekers over to Europe have pulled the strings of the European politics, both at national and international levels. Migration has been the best opportunity for far-right movements along the European Union to gain political relevance. Political groups have taken advantage of the situation in order to produce a grey migratory definition, combining both legal and illegal migration, together with

\footnotetext{
${ }^{60}$ Italian Parliament, Commissione congiunte $4^{\mathrm{a}}$ (Difesa) del Senato della Repubblica e IV (Difesa) della Camera dei deputati, Audizione dell' ammiraglio di divisione Enrico Credendino, Operation Commander della divisione EUNAVFOR MED - Operazione SOPHIA (February 2016)

${ }^{61}$ Garelli, G., Tazzioli M., (2017), The Humanitarian War Against Migrant Smugglers at Sea, Forthcoming, Antipode. Supra note. p. 696.

${ }^{62}$ Six Monthly Report . Supra note. p. 19.

${ }^{63}$ Audizione del Procuratore della Reppublica presso il Tribunale di Catania, Carmelo Zuccaro (9 May 2017).

${ }^{64}$ Ventrella, M. (2016). The impact of Operation Sophia on the exercise of criminal jurisdiction against migrant smugglers and human traffickers. Supra note. p. 17.

${ }^{65}$ See Article 3 of the Council Regulation (EU) 2017/1939. European Union: Council of the European Union. (2017, October 12). Council Regulation (EU) 2017/1939 of 12 October 2017 implementing enhanced cooperation on the establishment of the European Public Prosecutor's Office ('the EPPO'). O.J. L 283/1 31/10/2017. Available at https://eur-lex.europa.eu/legal-content/EN/TXT/HTML/?uri=CELEX:32017R1939\&from=EN

${ }^{66}$ Treaty on the Functioning of the European Union. Supra note. Article 86.
}

Revista de Direito Brasileira | São Paulo, SP | v. 20 | n. 8 | p. 19-42 |Mai./Ago. 2018 
applicants for international protection, for gaining support among voters. A new right-winged movement lead by Austrian chancellor Sebastian Kurz called for the formation of an "antimigration axis", together with Italy and Germany (where the German interior minister Horst Seehofer confronts Angela Merkel's open doors policy). ${ }^{67}$ The proposal comes after Italy closed it's ports to a rescue ship carrying over 600 refugees.

In fact, Italy has been the first EU Member State sparking the current crisis by closing the country's ports to foreign-flagged migrant rescue ships, after populist-right party Five StarLeague coalition coming to government in the elections of March 2018. After that, Italy refused to tack back any migrants stopped at the German border, and threatened to close ports and withdraw from Operation Sophia if the European Union doesn't establish a distribution system for arriving migrants and asylum-seekers. ${ }^{68}$ Austria and Germany's interior minister joined the Italian government backing these ideals. In a joint statement by Seehofer and Kurz, both explained that their goal is to tackle irregular migration in order to avoid situations like the one taking place after 2015 . $^{6}$

In the meanwhile, tension and debate over the involved countries increases together with the debate on migration situation that fosters the support to the far-right anti-immigration movements. In Germany, the far-right Alternative for Germany (AfD) is currently hitting a record high, as support for Chancellor Angela's Merkel bloc decreases. ${ }^{70}$

On the other side of the coin, countries like Germany, France and Spain support the EUwide approach to migration, with Spain accepting the rejected 600 migrants boat that tried to arrive to Italy. Tensions between the two blocks reached its top when France President Emmanuel Macron accused Rome of cynicism and irresponsibility after refusing to take the ship. 71

The Italy, Austria and Germany "axis" has called for the reinforcement of the EU's external borders, by militarization, with the HR replying that military operations under the CSDP frame can only take place outside the EU's territory. ${ }^{72}$ The obvious divide between the two blocks could endanger EUNAVFOR MED's future, as Italy threatens to withdraw from the fight against smugglers and traffickers if the European Union doesn't revise the Operation's mandate regarding disembarkation of migrants and asylum-seekers. Rome asserted it will no longer allow for disembarkation on its ports. ${ }^{73}$ Implications and consequences are to be asserted in future Political and Security Commission meetings.

Hungary has been the last country to join the political centre in migration matters. The country that erected a barbed wire fence along its borders with Croatia and Serbia to prevent

\footnotetext{
${ }^{67}$ Stone, J. (2018, June 14). Austria's chancellor calls for anti-migration 'axis' with Germany and Italy. Independent. Retrieved from https://www.independent.co.uk/news/world/europe/austria-sebastian-kurz-anti-migration-germanyitaly-refugee-crisis-eu-a8398756.html

${ }^{68}$ Oppenheim, M. (2018, Sunday 8). Italy's far-right government asks EU to block refugee ships from its ports. Independent. Retrieved from https://www.independent.co.uk/news/world/europe/italy-government-eu-block-refugeeships-matteo-salvini-ports-a8437516.html

${ }^{69}$ Carbajosa, A, Verdú, M. (2018, June 14). Los ministros del interior de Roma, Belín y Viena forjan un eje de mano dura contra la inmigración. El País. $\quad$ Retrieved https://elpais.com/internacional/2018/06/13/actualidad/1528907396_461186.html

${ }^{70}$ Support for Merkel's bloc hits record low, AfD at new high: poll. (2018, August 2). Reuters. Retrieved from https://www.reuters.com/article/us-germany-politics/support-for-merkels-bloc-hits-record-low-afd-at-new-high-pollidUSKBN1KN2U7

${ }^{71}$ Mulholland, R., Strange, H. (2018, June 14). Macron says he 'never meant to offend' Italy in row over migrant boat. The Telegraph. Retrieved from https://www.telegraph.co.uk/news/2018/06/14/macron-apologises-italy-rowmigrant-boat-continues/

${ }^{72}$ De Miguel, B. (2018, August 31). El choque entre Italia y Francia revienta la política migratioria de la UE. El País. Retrieved from https://elpais.com/internacional/2018/08/30/actualidad/1535628451_498059.html

${ }^{73}$ Italy to leave EU Operation Sophia, withdraws from human trafficking fight. (2018, July 19). Agencia EFE. Retrieved from https://www.efe.com/efe/english/world/italy-to-leave-eu-operation-sophia-withdraws-from-humantrafficking-fight/50000262-3696117\#
} 
migrants from crossing the Balkan route to Europe, and rejected to participate in the EU policy on resettlement, ${ }^{74}$ is now facing possible sanctions by the EU after the European Parliament successfully voted on a proposal to the Council of the EU to act against Hungary under Article 7 TEU for breach of the EU's founding values. In particular, Parliament's key concerns include the independence of Hungarian judicial system, corruption, freedom of religion or the fundamental rights of migrants, asylum-seekers and refugees. ${ }^{75}$ This is the first time this procedure is activated, and the Council will now determine whether there is a serious breach of the EU values in Hungary, eventually leading to sanctions, such as the suspension of the voting rights in the Council for Hungary.

Finally, some argue that Viktor Orban, the Hungarian leader, could be orchestrating the formation of a new alliance of the far-right movements along Europe in the European Parliament. ${ }^{76}$ It could bring together populist right-wing parties from Hungary, Germany, Poland, Italy, Sweden, Austria, Denmark, and France, and split from the European People's Party (EPP Group), where some of them are integrated.

Being this the political situation, the EU heads of state or government are gathering in Salzburg on 19-20 September 2018 in an informal meeting under the Austrian Presidency of the Council of the European Union, where internal security and migration are to be discussed.

\subsubsection{Heading towards a Better CSDP Integration?}

Could maritime security in the Mediterranean be a future integration pillar for the Common Security and Defense Policy? After the sinking tragedy in 2015, the European Union declared war on smugglers and traffickers operating in the Mediterranean Sea. But the existing threats are not only related to migration: the Mediterranean Sea has become a route of trafficking drugs, arms, and money. ${ }^{77}$ The interests of the EU as well as peace and security are directly affected by the situation in the Mediterranean.

As geopolitics swift to the sea, understanding how, why, and in what way the European Union establishes itself as a maritime actor is relevant for the broader international relations community. The involvement of the EU with Operation Sophia challenges the commonly held assumption that the EU will act as a "soft power" at sea. ${ }^{78}$ Nevertheless, since the launch of Operation Atalanta, and the adoption of the Integrated Maritime Policy, maritime security has been one of the fastest growing areas of EU security integration.

Atalanta and Sophia have been highly successful regarding defence integration. Participating Member States and the support provided by them to the naval operations proves so. In fact, the launching of naval operations for crisis management could be seen as a step forward for the creation of a Security and Defence Union. ${ }^{79}$ Furthermore, after Brexit, defence integration can be enhanced, after the UK leaving, which has always been reluctant to support any EU

\footnotetext{
${ }^{75}$ European Parliament. (2018, September 9). Rule of law in Hungary: Parliament calls on the EU to act. (Press release). Retrieved from http://www.europarl.europa.eu/news/en/press-room/20180906IPR12104/rule-of-law-inhungary-parliament-calls-on-the-eu-to-act

76 Byrne, A. (2018, September 16). Fears that Viktor Orban plans to create a powerful far-right alliance across Europe. The Times. Retrieved from https://www.thetimes.co.uk/article/fears-that-viktor-orban-plans-to-create-apowerful-far-right-alliance-across-europe-c8cv77kq6

77 Seiti, E-C. (2017, March 28). Integrating maritime security operations in the Mediterranean. Center for International Maritime Security. Retrieved from http://cimsec.org/integrating-maritime-security-operations-in-themediterranean $/ 31235$

78 Riddervold, M., The Maritime turn in EU Foreign and Security Policies. Aims, Actors and Mechanisms of Integration. Supra note. p. 103.

${ }^{79}$ Espaliú Berdud, C. (2018). Taking European defence seriously: The naval operations of the European Union as a model for a Security and Defence Union. Cuadernos Europeos de Deusto. Volume 58, p. 159, and pp. 157-183.

Revista de Direito Brasileira | São Paulo, SP | v. 20 | n. 8 | p. 19-42 |Mai./Ago. 2018
} 
operations, and always backed the North Atlantic Treaty Organization (NATO) led operations. In fact, during the Bratislava Summit on 16 September 2016, the first after Brexit, a priority was set aiming to reinforce cooperation in the European Union regarding external security and defence matters. $^{80}$

Moreover, the European Parliament passed on 22 November 2016 a resolution proposing that all Member States should increase military expenditure and that the European Union should take an active role regarding security matters alongside with NATO. ${ }^{81}$ Furthermore, on 11 December 2017, the Council of the EU adopted Council Decision (CFSP) 2017/2315, establishing the Permanent Structured Cooperation (PESCO) and determining a list of participating Member States. ${ }^{82}$

Those measures came in just a moment when the security and migration were top concern among Europeans. ${ }^{83}$ At the same time, future president of the United States of America, candidate Donald J. Trump, stated that he was going to let Europe take its security in its own hands. ${ }^{84}$ Also, the annexation of Crimea by the Russian Federation raised a major concern over the European citizens. To face all of this challenges, the European Union must react as a whole. According to the report published by the EU Institute for Security Studies in 2016, "no single European country is able to manage the violent conflicts, hybrid warfare challenges and sophisticated cyber-attacks now taking place around Europe on its own". ${ }^{85}$

Probably, the time for PESCO has come, and Operation Sophia could have acted as a trial when it came to Defence Integration in the European Union. The EU must be aware that security threats in the sea do not only concern coastal states, but all the Member States.

\section{REFERENCES}

Arenas, N., (2016), Flujos masivos de población y seguridad. La crisis de personas refugiadas en el Mediterráneo, Araucaria, Revista Iberoamericana de Filosofía, Política y Humanidades, Volume 18 (36), pp. 339-372.

Audizione del Procuratore della Reppublica presso il Tribunale di Catania, Carmelo Zuccaro (9 May 2017).

Baczynska, G. (2018, July 8). EU migration policies seen building blocks for 'Fortress Europe', Reuters. Retrieved from https://uk.reuters.com/article/uk-europe-migrants-analysis/eu-migrationpolicies-seen-building-blocks-for-fortress-europe-idUKKBN1JY07V

\footnotetext{
${ }^{80}$ European Council. (2016, September 16). European Union, Infomal meeting of the 27 heads of state or governemnt, Bratislava Declaration and Roadmap. Retrieved from http://www.consilium.europa.eu/media/21250/160916-bratislava-declaration-and-roadmapen16.pdf

${ }^{81}$ European Parliament. (2016, November 22). Defence: MEPs push for more EU cooperation to better protect Europe. (Press release). Retrieved from http://www.europarl.europa.eu/news/en/pressroom/20161117IPR51547/defence-meps-push-for-more-eu-cooperation-to-better-protect-europe

${ }^{82}$ European Union: Council of the European Union. (2017, December 11) Council Decision (CFSP) 2017/2315 establishing permanent structured cooperation (PESCO) and determining the list of participating Member States. O.J. L331/57.

${ }^{83}$ European Commission. (2016, December 22). Autumn 2016 Standard Eurobarometer: Immigration and terrorism continue to be seen as the most importsant issues facing the EU. Retrieved from https://ec.europa.eu/homeaffairs/news/autumn-2016-standard-eurobarometer-immigration-and-terrorism-continue-be-seen-most-important_en

${ }^{84}$ Ellyatt, H. (2018, July 11). Trump's NATO criticism is 'valid', Europe isn't spending enough on defense, UK exminister says. CNBC. Retrieved from https://www.cnbc.com/2018/07/11/trumps-nato-criticism-is-valid-europe-isntspending-enough-on-def.html

${ }^{85}$ Joel Andersson, J, Biscop, S, Giegrich, B, Mölling, C \& Tardy, T. (2016). Future V: European army, in Envisioning European Defence: five futures, Chaillot Papers 137, EU Institute for Security Studies. p. 31.
} 
Belgian migration minister describes the EU migrant rescue mission as 'pure lunacy' that is causing more deaths as he calls for Belgium's frigate to leave the Mediterranean. (2017, July 16). The Daily Mail. Retrieved from https://www.dailymail.co.uk/news/article-4701224/Belgiumfrigate-migration-mission-Libya-minister.html

Berry, M., Garcia-Blanco, I., \& Moore, K. (2016). Press coverage of the refugee and migrant crisis in the EU: A content analysis of five European countries. Project report. Geneva: United Nations High Commissioner for Refugees. Retrieved from http://www.unhcr.org/56bb369c9.html

Bonomolo A., Kirchgaessner S. (2015, April 20). UN says 800 migrants dead in boat disaster as Italy launches rescue of two more vessels. The Guardian. Retrieved from https://www.theguardian.com/world/2015/apr/20/italy-pm-matteo-renzi-migrant-shipwreckcrisis-srebrenica-massacre.

Bulman, M (2017, July 12). EU refugee anti-smuggling mission is driving deaths in the Mediterranean, finds report. The Independent. Retrieved from https://www.independent.co.uk/news/world/europe/eu-refugee-rescue-mission-mediterraneanpeople-smuggling-north-africa-report-migrant-crisis-european-a7835631.html

Byrne, A. (2018, September 16). Fears that Viktor Orban plans to create a powerful far-right alliance across Europe. The Times. Retrieved from https://www.thetimes.co.uk/article/fears-thatviktor-orban-plans-to-create-a-powerful-far-right-alliance-across-europe-c8cv77kq6

Carbajosa, A, Verdú, M. (2018, June 14). Los ministros del interior de Roma, Belín y Viena forjan un eje de mano dura contra la inmigración. El País. Retrieved from https://elpais.com/internacional/2018/06/13/actualidad/1528907396_461186.html

Chetail, V. (2016). Reforming the Common European Asylum System: The New European Refugee Law. International Journal of Refugee Law, Volume 29 (2).

Clarke, L. (2018, June 28). In the hands of the Libyan Coast Guard: pushbacks by proxy. Open Migration. Retrieved from https://openmigration.org/en/analyses/in-the-hands-of-the-libyancoast-guard-pushbacks-by-proxy/

D’Argent, P., Kuritzky, M., (2017), Refoulement by proxy? The Mediterranean migrant crisis and the training of Libyan Coast Guard by EUNAVFO MED Operation Sophia, Israel Yearbook on Human Rights, Volume 47 (2017), pp. 233-264.

Dearden, L., (2017, June 9). Refugee rescue ships not acting as 'pull factor' or 'colluding with people smugglers', report finds. Independent. Retrieved from https://www.independent.co.uk/news/world/europe/refugee-crisis-europe-rescue-boats-ngos-pullfactor-collusion-smugglers-report-debunked-goldmiths-a7782781.html

De Miguel, B. (2018, August 31). El choque entre Italia y Francia revienta la política migratioria de la UE. El País. https://elpais.com/internacional/2018/08/30/actualidad/1535628451_498059.html Elaradi, H. (2017, July 31). The failure of Libya's EU-Backed Coastguard, Atlantic Council http://www.atlanticcouncil.org/blogs/menasource/the-failure-of-libya-s-eu-backed-coastguard 
Ellyatt, H. (2018, July 11). Trump's NATO criticism is 'valid', Europe isn't spending enough on defense, UK ex-minister says. CNBC. Retrieved from https://www.cnbc.com/2018/07/11/trumpsnato-criticism-is-valid-europe-isnt-spending-enough-on-def.html

Espaliú Berdud, C. (2018). Taking European defence seriously: The naval operations of the European Union as a model for a Security and Defence Union. Cuadernos Europeos de Deusto. Volume 58. pp. 157-183.

European Commission, Communication from the Commission to the European Parliament, the Council, the European Economic and Social Committee and the Committee of the Regions. $A$ European Agenda of Migration, 13 May 2015, COM(2015) 240 final.

European Commission, Europe is declaring war on smugglers, Remarks by Commissioner Avramopoulos at the press conference in Castille Place, Malta, 23 April 2015.

European Commission. (2015, October 15). EU-Turkey joint action plan. (Press release). Retrieved from http://europa.eu/rapid/press-release_MEMO-15-5860_en.htm

European Commission. (2016, June 22) press release, European Border and Coast Guard agreed. (Press release). Retrieved from http://europa.eu/rapid/press-release_IP-16-2292_en.htm

European Commission. (2016, July 13). Proposal for a Regulation of the European Parliament and of the Council establishing a Union Resettlement Framework and amending Regulation (EU) No 516/2014 of the European Parliament and the Council. COM (2016) 468 final.

European Commission. (2016, October 4). EU Operations in the Mediterranean. Available at https://ec.europa.eu/home-affairs/sites/homeaffairs/files/what-we-do/policies/securing-euborders/fact-sheets/docs/20161006/eu_operations_in_the_mediterranean_sea_en.pdf.

European Commission. (2016, December 22). Autumn 2016 Standard Eurobarometer: Immigration and terrorism continue to be seen as the most importsant issues facing the EU. Retrieved from https://ec.europa.eu/home-affairs/news/autumn-2016-standard-eurobarometerimmigration-and-terrorism-continue-be-seen-most-important_en

European Commission. (July 2017). The EU and the Migration Crisis. Retrieved from http://publications.europa.eu/webpub/com/factsheets/migration-crisis/en/

European Commission. (2018, June 26). Central Mediterranean Route: Protecting Migrants and Managing Irregular Flows. (Press release). Retrieved from https://eeas.europa.eu/sites/eeas/files/central_med_route_v6.pdf

European Commission. (2018, September 12). A strengthened and fully equipped European Border and Coast Guard. (Press release). Retrieved from https://ec.europa.eu/commission/sites/beta-political/files/soteu2018-factsheet-coast-guard_en.pdf

European Commission. (2018, September 12). Amended proposal for a Regulation on the European Union Agency for Asylum and Repealing Regulation (EU) No439/2010. COM(2018) 633 final. Available at https://ec.europa.eu/commission/sites/beta-political/files/soteu2018-euagency-asylum-regulation-633_en.pdf 
European Commission (2018, September 12). Communication from the Commission to the European Parliament and the Council. Enhancing legal pathways to Europe: an indispensable part of a balanced and comprehensive migration policy. Retrieved from https://ec.europa.eu/commission/sites/beta-political/files/soteu2018-legal-pathways-europecommunication-635_en.pdf

European Commission. (2018, September 12). State of the Union 2018: A reinforced European Union Agency for Asylun - Questions and Answers. (Press release). Retrieved from http://europa.eu/rapid/press-release_MEMO-18-5714_en.htm

European Council. (2016, September 16). European Union, Infomal meeting of the 27 heads of state or governemnt, Bratislava Declaration and Roadmap. Retrieved from http://www.consilium.europa.eu/media/21250/160916-bratislava-declaration-androadmapen16.pdf

European Council. (2018, June 29). European Council conclusions, 28 June 2018. (Press release). Retrieved from http://www.consilium.europa.eu/en/press/pressreleases/2018/06/29/20180628-euco-conclusions-final/

European External Action Service. (2010, August 9). EU \& Kenya co-operate to prosecute pirates. Retrieved from http://eunavfor.eu/eu-kenya-co-operate-to-prosecute-pirates/

European External Action Service. (2015, April 25). EUNAVFOR MED, MISSION. Retrieved from https://eeas.europa.eu/sites/eeas/files/april_2017__factsheet_on_eunavfor_med_mission_english.pdf

European External Action Service. EUNAVFOR SOMALIA. Countering Piracy off the Coast of Somalia. Retrieved from http://eunavfor.eu

European Parliament. (2016, November 22). Defence: MEPs push for more EU cooperation to better protect Europe. (Press release). Retrieved from http://www.europarl.europa.eu/news/en/press-room/20161117IPR51547/defence-meps-push-formore-eu-cooperation-to-better-protect-europe

European Parliament. (2018, September 9). Rule of law in Hungary: Parliament calls on the EU to act. (Press release). Retrieved from http://www.europarl.europa.eu/news/en/pressroom/20180906IPR12104/rule-of-law-in-hungary-parliament-calls-on-the-eu-to-act

European Union: Consolidated version of the Treaty on the Functioning of the European Union, 13 December 2007. O.J. C326/01, 26 October 2012.

European Union: Council of the European Union. Council Decision 2015/778 of 18 May 2015 on a European Union military operation in the Southern Central Mediterranean (EUNAVFOR MED). 19 May 2015. O.J. L122/31

European Union: Council of the European Union, Council Decision (EU) 2015/1601 of 22 September 2015 establishing provisional measures in the area on international protection for the benefit of Italy and Greece. 24 September 2015, L 248/80. 
European Union: Council of the European Union. (2017, December 11) Council Decision (CFSP) 2017/2315 establishing permanent structured cooperation (PESCO) and determining the list of participating Member States. O.J. L331/57.

European Union: Council of the European Union. Council Regulation (EU) 2017/1939 of 12 October 2017 implementing enhanced cooperation on the establishment of the European Public Prosecutor's Office ('the EPPO'). 12 October 2017. O.J. L 283/1 31/10/2017.

European Union: Council of the European Union. Regulation (EU) No 604/2013 of the European Parliament and of the Council, of 26 June 2013, establishing the criteria and mechanisms for determining the Member State responsible for examining an application for international protection lodged in one of the Member States by a third-country national or a stateless person. 29 June 2013. O.J. L. 180/31-180/59, (EU) No 604/2013.

Garelli, G., Tazzioli M., The Humanitarian War Against Migrant Smugglers at Sea, Forthcoming, Antipode, Volume 50(3) 'Mediterranean Movements: Mobility Struggles, Border Restructuring, and The Humanitarian Frontier'), 2015, pp. 685-703.

Grandi, F. (2016). Speech by Filippo Grandi, United Nations High Commissioner for Refugees, at the European Policy Centre, Brussels 5/12-2016. Available at http://www.unhcr.org/admin/58456ec34/protecting-refugees-europe-beyond-eu-risechallenge.html

Henley, J. (2018, June 27). EU migration crisis: what are the key issues? The Guardian. https://www.theguardian.com/world/2018/jun/27/eu-migration-crisis-what-are-the-issues

House of Lords (2016), Operation Sophia, the EU's naval mission in the Mediterranean: an imposible challenge, European Union Committee, 14th Report of Session 2015-16, retrieved from https://publications.parliament.uk/pa/ld201516/ldselect/ldeucom/144/144.pdf

House of Lords (2017), Operation Sophia, a failed mission, European Union Committee, $2^{\text {nd }}$ Report of Session 2017-2019.

Humanitarian NGOs conducting Search and Rescue Operations at Sea: A “pull factor"? (August 2017). Médecins Sans Frontières. Issue brief. Retrieved from http://searchandrescue.msf.org/assets/uploads/files/170831_Analysis_SAR_Issue_Brief_Final.pd $\mathrm{f}$

Ingemann Johansen, A., (2017), Assesing the European Union's Strategic Capacity: The Case of EUNAVFOR MED Operation Sophia, Journal on European Security, Volume 26, pp. 507-526.

International Law Commission, Draft Articles on Responsibility of States for Internationally Wrongful Acts. November 2001, Supplement No. 10 (A/56/10), chp. I.V.E.1.

International Organization for Migration. (updated 2018, September 17). Missing Migrants Project. Tracking deaths along migratory routes. Central Mediterranean. Retrieved from https://missingmigrants.iom.int/region/mediterranean?migrant_route\%5B\%5D=1376 
Italian Parliament, Commissione congiunte $4^{\mathrm{a}}$ (Difesa) del Senato della Repubblica e IV (Difesa) della Camera dei deputati, Audizione dell' ammiraglio di divisione Enrico Credendino, Operation Commander della divisione EUNAVFOR MED - Operazione SOPHIA (February 2016)

Italy to leave EU Operation Sophia, withdraws from human trafficking fight. (2018, July 19). Agencia EFE. Retrieved from https:/www.efe.com/efe/english/world/italy-to-leave-eu-operationsophia-withdraws-from-human-trafficking-fight/50000262-3696117\#

Joel Andersson, J, Biscop, S, Giegrich, B, Mölling, C \& Tardy, T. (2016). Future V: European army, in Envisioning European Defence: five futures, Chaillot Papers 137, EU Institute for Security Studies.

Ministerio Della Difesa, Mare Nostrum Operation, http://www.marina.difesa.it/EN/operations/Pagine/MareNostrum.aspx. Accessed 17 Jul 2018.

Mulholland, R., Strange, H. (2018, June 14). Macron says he 'never meant to offend' Italy in row over migrant boat. The Telegraph. Retrieved from https://www.telegraph.co.uk/news/2018/06/14/macron-apologises-italy-row-migrant-boatcontinues/

Oppenheim, M. (2018, Sunday 8). Italy's far-right government asks EU to block refugee ships from its ports. Independent. Retrieved from https://www.independent.co.uk/news/world/europe/italy-government-eu-block-refugee-shipsmatteo-salvini-ports-a8437516.html

Peen Rodt, A. (2012). EU performance in military conflict management. In The European Union as a Global Conflict Manager. New York. ed. by Richard G. Whitman, and Stefan Wolff (Abingdon Routledge, 2012). pp. 169-183.

Riddervold, M., The Maritime turn in EU Foreign and Security Policies. Aims, Actors and Mechanisms of Integration, Palgrave MacMillan, ed 1 (2017), Switzerland.

Seiti, E-C. (2017, March 28). Integrating maritime security operations in the Mediterranean. Center for International Maritime Security. Retrieved from http://cimsec.org/integratingmaritime-security-operations-in-the-mediterranean/31235

Senato della Repubblica. (2016). Audizione dell' ammiraglio di divisione Enrico Credendino, Operation Commander della operatione EUNAVFOR MED - Operazione Sophia. 18 ${ }^{a}$ seduta, 4 febbraio, AU 0683. Roma: Senato della Repubblica.

Statista, Number of rescued migrants with the Operation Mare Nostrum from 2005 to 2014, in Italy. 2015. Retrieved from https://www.statista.com/statistics/579418/number-ofrescuedmigrants-operation-mare-nostrum-italy/

Stone, J. (2018, June 14). Austria's chancellor calls for anti-migration 'axis' with Germany and Italy. Independent. Retrieved from https://www.independent.co.uk/news/world/europe/austriasebastian-kurz-anti-migration-germany-italy-refugee-crisis-eu-a8398756.html

Support for Merkel's bloc hits record low, AfD at new high: poll. (2018, August 2). Reuters. Retrieved from https:/www.reuters.com/article/us-germany-politics/support-for-merkels-bloc- 
hits-record-low-afd-at-new-high-poll-idUSKBN1KN2U7Tardy, T., (2015), Operation Sophia. Tackling the refugee crisis with military means, European Union Institute for Security Studies, Sep 2015, retrieved from https://www.iss.europa.eu/sites/default/files/EUISSFiles/Brief_30_Operation_Sophia.pdfThe Guardian, EU's policy of helping Libya intercept migrants is 'inhuman', says UN, 2017. Retrieved from https://www.theguardian.com/world/2017/nov/14/eu-libya-coastguard-detentioncentres-migration-mediterranean-un-zeid-raad-al-husseinUnited Nations General Assembly, Convention Against Torture and Other Cruel, Inhuman or Degrading Treatment or Punishment, 10 December 1984, United Nations, Treaty Series, Vol. 1465, p. 85.United Nations General Assembly, Responsibility for States for internationally wrongful acts, Art 16. 28 Jan 2002, A/RES/56/83.

United Nations Security Council, Security Council Resolution 1851 (2008), on the fight of piracy and armed robbery at sea off the coast of Somalia.16 December 2008. S/RES/1851 (2008).

United Nations Security Council, Security Council Resolution 2240 (2015) on migrant smuggling and human trafficking into, through and from the Libyan territory and off the coast of Libya. 9 October 2015. S/RES/2240 (2015). United Nations Security Council, Security Council Resolution 2292 (2016), on the situation in Libya of 14 June 2016, S/RES/2292(2016).

Ventrella, M. (2016), The impact of Operation Sophia on the exercise of criminal jurisdiction against migrant smugglers and human traffickers, Questions of International Law, Volume 30, pp. 3-18.WikiLeaks. (2016). EUNAVFOR MED Op Sophia (2016) - Six Monthly Report 22 June-31 December 2015. Retrieved from https://wikileaks.org/eu-military-refugees/EEAS/EEAS-2016126.pdf 